\title{
Communications
}

\section{A Shortcut to the Preparation of Naturally Occurring Arbutin}

\author{
Jia-Lu Xue, ${ }^{\dagger}$ Jin-Wei Yang, ${ }^{\dagger}$ Qiong Deng, ${ }^{\dagger}$ Xiao-Peng He, ${ }^{\dagger, *, *}$ and Guo-Rong Chen ${ }^{\dagger, *}$ \\ ${ }^{\dagger}$ Key Laboratory for Advanced Materials and Institute of Fine Chemicals, East China University of Science and Technology, \\ 130 Mei Long Road, Shanghai, P. R. China. *E-mail: mrs_guorongchen@ecust.edu.cn \\ *Department of Pharmaceutical Engineering, School of Pharmacy, East China University of Science and Technology, \\ 130 Mei Long Road, Shanghai, P. R. China. ${ }^{*}$-mail: frogmaster_eminem@yahoo.com.cn \\ Received January 29, 2010, Accepted February 25, 2010
}

Key Words: Arbutin, Microwave irradiation, Hydroquinone, Glycosylation

Naturally occurring arbutin (4-hydroxyphenyl $\beta$-D-glucopyranoside) was initially isolated from medical plants such as bearberry leaves (Arctostaphylos uvae ursi), etc. ${ }^{1}$ Besides the multiple pharmaceutical applications it owns, arbutin is also well-known as a green, reliable and highly efficient skin-whitening agent, which effectively inhibits human tyrosinase. ${ }^{2}$ The preparation of arbutin mainly falls into two pathways: organic synthesis and enzymatic glycosylation. Indeed, since the first chemical approach to arbutin was realized from tetra- $O$-acetyl$\alpha$-bromo-D-glucopyranoside with hydroquinone in the last century, ${ }^{3}$ various other strategies have been successively developed. Among which, penta- $O$-acetyl- $\beta$-D-glucopyranoside seems to be the most utilized glyco-donor. ${ }^{4}$ More recently, Cepanec et al . reported a simple and efficient synthesis starting from penta$O$-acetyl- $\beta$-D-glucopyranoside and 4-hydroxyphenylacetate catalyzed via $\mathrm{BF}_{3} \cdot \mathrm{Et}_{2} \mathrm{O}$ in a total yield of around $50 \%$. ${ }^{5}$ Nevertheless, although these glycosylations proceeded smoothly and afforded effectively the final product, there still remain several drawbacks such as incomplete anomeric retention, relatively low total yield and especially, long reaction time (commonly more than $24 \mathrm{~h}$ for 2 - 3 steps).

Microwave irradiation is known as a powerful tool for both enhancing the reaction efficacy and economizing the reaction time. To our surprise, though this methodology has been massively introduced into carbohydrate chemistry, ${ }^{6}$ its elongation to the preparation of arbutin is still unreported. Consequently, with a continuing interest on arbutin and its derivatives, ${ }^{7}$ we describe here a shortcut to the synthesis of arbutin via microwave irradiation.

\section{Experimental Section}

Solvents were purified by standard procedures. ${ }^{1} \mathrm{H}$ NMR spectra were recorded on a Bruker DRX500 spectrometer in $\mathrm{CDCl}_{3}$ or $\mathrm{D}_{2} \mathrm{O}$ solutions. Microwave-assisted syntheses were performed in a Whirlpool VIP273F system. Optical rotations were measured using a SG WZZ-2A polarimeter at room temperature and a $10 \mathrm{~cm} 1 \mathrm{~mL}$ cell. Column chromatography was performed on E. Merck Silica Gel 60 (230 - 400 mesh). Analytical thin-layer chromatography was performed on E. Merck aluminum percolated plates of Silica Gel 60F-254 with detection by UV and by spraying with $6 \mathrm{~N} \mathrm{H}_{2} \mathrm{SO}_{4}$ and heating at 300 ${ }^{\circ} \mathrm{C}$. High resolution mass spectra (HRMS) were recorded on a KE465 LCT Premier/XE instrument using standard conditions (ESI, $70 \mathrm{eV}$ ).

Preparation of tetra- $\boldsymbol{O}$-acetyl-arbutin (2). To a soln. of penta$O$-acetyl- $\beta$-D-glucopyranoside $(200 \mathrm{mg}, 0.5 \mathrm{mmol})$ and hydroquinone $(112.4 \mathrm{mg}, 1.0 \mathrm{mmol})$ in $\mathrm{MeOH}(10 \mathrm{~mL})$, was added dry $\mathrm{BF}_{3} \cdot \mathrm{Et}_{2} \mathrm{O}(40.8 \mu \mathrm{L}, 0.2 \mathrm{mmol})$. This was then transferred to the microwave oven $(240 \mathrm{~W})$ for $10 \mathrm{~min}$. After completion of the reaction monitored by TLC, the mixture was evaporated, washed with brine, extracted with $\mathrm{CH}_{2} \mathrm{Cl}_{2}$ and dried over $\mathrm{MgSO}_{4}$. The dried organic layer was concentrated, then purified by column chromatography (petroleum ether/EtOAc; $3: 1$ ) to give the known $2^{8}$ as a white solid (140.2 $\left.\mathrm{mg}, 62.1 \%\right)$. TLC $R_{f}=$ 0.57 (petroleum ether/EtOAc; 3:1). ${ }^{1} \mathrm{H} \mathrm{NMR}\left(500 \mathrm{MHz}, \mathrm{CDCl}_{3}\right)$ $\delta 6.88(\mathrm{dd}, 2 \mathrm{H}, J=2.2,6.7 \mathrm{~Hz}), 6.75(\mathrm{dd}, 2 \mathrm{H}, J=2.2,6.7 \mathrm{~Hz})$, $5.28-5.22(\mathrm{~m}, 2 \mathrm{H}), 5.16(\mathrm{t}, 1 \mathrm{H}, J=9.2,9.8 \mathrm{~Hz}), 4.94(\mathrm{~d}, 1 \mathrm{H}, J=$ $7.6 \mathrm{~Hz}), 4.30(\mathrm{dd}, 1 \mathrm{H}, J=5.2,12.3 \mathrm{~Hz}), 4.20(\mathrm{dd}, 1 \mathrm{H}, J=2.4$, $12.2 \mathrm{~Hz}), 3.82-3.78$ (m, 1H), 2.10, 2.08, 2.04, 2.02 (4s, 12H).

Preparation of arbutin (1). To a soln. of 2 (140.2 mg, 0.3 $\mathrm{mmol})$ in $\mathrm{MeOH}(10 \mathrm{~mL})$, was added $28 \%$ ammonia water $(0.17 \mathrm{~mL}, 4.5 \mathrm{mmol})$ which was then transferred to the microwave oven $(240 \mathrm{~W})$ for $10 \mathrm{~min}$. The mixture was evaporated to directly afford the desired $\mathbf{1}$ as sole product (white powder, $86.6 \mathrm{mg}, 99 \%)$. TLC $R_{f}=0.48\left(\mathrm{AcOH} / \mathrm{H}_{2} \mathrm{O} / n-\mathrm{BuOH} ; 1: 5: 3\right)$; $[\alpha]_{\mathrm{D}}^{20}=-33.7(c=0.5, \mathrm{MeOH}) ;{ }^{1} \mathrm{H} \mathrm{NMR}\left(500 \mathrm{MHz}, \mathrm{D}_{2} \mathrm{O}\right) \delta$ $6.81(\mathrm{~d}, 2 \mathrm{H}, J=9.0 \mathrm{~Hz}), 6.62(\mathrm{~d}, 2 \mathrm{H}, J=9.0 \mathrm{~Hz}), 4.82(\mathrm{~d}, 1 \mathrm{H}$, $J=7.4 \mathrm{~Hz}$ ), 3.80-3.21 (m, 6H); HRMS: calcd for $\mathrm{C}_{12} \mathrm{H}_{16} \mathrm{O}_{7}+\mathrm{Na}$ : 295.0794, found: 295.0788 .

\section{Result and Discussion}

As shown in Table 1, we initially performed the Helferish glycosylation by employing penta- $O$-acetyl- $\beta$-D-glucopyranoside and hydroquinone as starting materials promoted via four different Lewis acids. Surprisingly, under microwave irradiation, $\mathrm{SnCl}_{4}$ and $\mathrm{BF}_{3} \cdot \mathrm{Et}_{2} \mathrm{O}$ catalyzed reactions favorably afforded the desired product ( 2 ) with complete retention of $\beta$-configuration within only ten minutes (entry 1,2 ). However, two solid 
Table 1. Preparation of arbutin via microwave irradiation (240 W, 10 min)
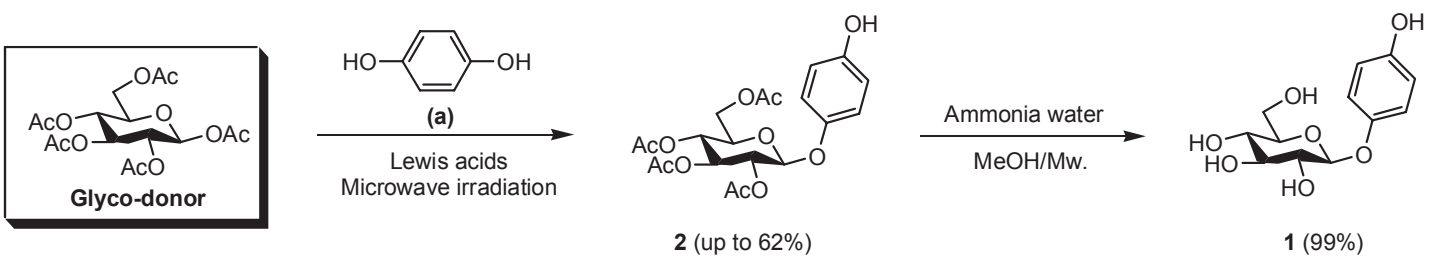

\begin{tabular}{ccccc}
\hline entry & a (equiv.) & Lewis acid & solvent & $\alpha: \beta$ (yield \%) \\
\hline $\mathbf{1}$ & 2 & $\mathrm{SnCl}_{4}(0.5$ equiv. & $\mathrm{CH}_{2} \mathrm{Cl}_{2}$ & $0: 1(41.1)$ \\
$\mathbf{2}$ & 2 & $\mathrm{BF}_{3} \cdot \mathrm{Et}_{2} \mathrm{O}(0.5$ equiv. & $\mathrm{CH}_{2} \mathrm{Cl}_{2}$ & $0: 1(52.7)$ \\
$\mathbf{3}$ & 2 & $4 \AA \mathrm{ms}(900 \mathrm{mg})$ & $\mathrm{CH}_{2} \mathrm{Cl}_{2}$ & - \\
$\mathbf{4}$ & 2 & $\mathrm{CH}_{2} \mathrm{Cl}_{2}$ & - \\
$\mathbf{5}$ & 2 & $\mathrm{Mont}_{2} \mathrm{~K}-10(900 \mathrm{mg})$ & $\mathrm{DMF}$ & - \\
$\mathbf{6}$ & 2 & $\mathrm{BF}_{3} \cdot \mathrm{Et}_{2} \mathrm{O}(0.5$ equiv. $)$ & $\mathrm{MFCN}_{3}$ & - \\
$\mathbf{7}$ & 2 & $\mathrm{BF}_{2} \mathrm{O}(0.5$ equiv. $)$ & $\mathrm{CH}_{2} \mathrm{Cl}_{2}$ & $0: 1(45.2)$ \\
$\mathbf{8}$ & 1.5 & $\mathrm{BF}_{3} \cdot \mathrm{Et}_{2} \mathrm{O}(0.5$ equiv. $)$ & $\mathrm{CH}_{2} \mathrm{Cl}_{2}$ & $0: 1(\mathbf{6 2 . 1})$ \\
$\mathbf{9}$ & 2 & $\mathrm{BF}_{3} \cdot \mathrm{Et}_{2} \mathrm{O}(0.3$ equiv. $)$ & & \\
\hline
\end{tabular}

acids (4 A molecular sieve and montmorillonite K-10) failed to promote the reaction (entry 3,4 ) under same condition. In addition, $\mathrm{BF}_{3} \cdot \mathrm{Et}_{2} \mathrm{O}$ catalyzed reaction more effectively afforded 2 with a yield of $52.7 \%$ (entry 2). Such result completely accords with the former report which indicated $\mathrm{BF}_{3} \cdot \mathrm{Et}_{2} \mathrm{O}$ as the most efficient glycosylation catalyst, providing clean reactions as well as high conversions. ${ }^{9}$ Prompted by such exciting outcome, optimization of the reaction condition was further actualized. Clearly, the yield decreased $(47.8 \%)$ when using $\mathrm{CHCl}_{3}$ as the solvent (entry 5) whereas aprotic solvents such as $\mathrm{DMF}$ and $\mathrm{MeCN}$ provided deleterious impact as no apparent reacting trace could be monitored (entry 6,7). As shown in entry 8 , lowering the loading of hydroquinone from 2 equiv. to 1.5 equiv. rendered yield decrease. Finally, the best yield $(62.1 \%$, entry 9) was obtained via a catalyst loading reduction from 0.5 equiv. to 0.3 equiv. within $10 \mathrm{~min}$. The desired final product (1) was then satisfactorily obtained by deprotection of $\mathbf{2}$ via ammonia water under microwave irradiation in almost quantitive yield (99\%) within another $10 \mathrm{~min}$.

In summary, we have efficiently and rapidly synthesized the naturally occurring arbutin via microwave irradiation. Using commercially available and inexpensive penta- $O$-acetyl- $\beta$-Dglucopyranoside and hydroquinone, such natural product was obtained through a simple expeditious 2-step workup including $\mathrm{BF}_{3} \cdot \mathrm{Et}_{2} \mathrm{O}$ catalyzed glycosylation and deprotection with considerable total yield of $>60 \%$ and complete retention of anomeric configuration. Most notably, thanks to the introduction of microwave irradiation, only 20 min were consumed for the reaction process from raw materials to the final product $\mathbf{1}$. To the best of our knowledge, such result represents the fastest access to the achievement of arbutin with comparable and retainable reaction efficiency among current relevant reports.

Acknowledgments. This work was supported by National Natural Science Foundation of China (Grant No.20876045) and Shanghai Science and Technology Community (No. 1041070 2700).

\section{Reference and Notes}

1. (a) Frohne, D. Planta Med. 1970, 18, 1. (b) Steglich, W.; Fugmann, B.; Lang, S. Rompp Lexikon-Naturestoffe; New York, Georg Thieme: 1997; p 53.

2. (a) Maeda, K.; Fukuda, M. J. Pharmacol. Exp. Ther. 1996, 276, 765. (b) Funayama, M.; Arakawa, H.; Yamamoto, R.; Nishino, T.; Shin, T.; Murao, S. Biosci. Biotechnol. Biochem. 1995, 59, 143. 3. Mannich, C. Arch. Pharm. 1912, 250, 547.

4. (a) Jarrett, A. U. S. Pat. Appl. 1965, 3201385. (b) Li, Z. J.; Cai, L. N.; Cai, M. S. Synth. Commun. 1992, 22, 2121. (c) Clerici, F.; Gelmi, M. L.; Mottadelli, S. J. Chem. Soc., Perkin Trans. 1 1994, 985. 5. Cepanec, I.; Litvic, M. Arkivoc 2008, 19.

6. For review, see: Corsaro, A.; Chiacchio, U.; Pistara, V.; Romeo, G. Curr. Org. Chem. 2004, 8, 511.

7. Wang, Z,-X.; Shi, X.-X.; Chen, G.-R.; Ren, Z.-H.; Luo, L.; Yan, J. Carbohyd. Res. 2006, 341, 1945.

8. Sisido, K. J. Soc. Chem. Ind. Japan 1936, 39, 217.

9. Toshima, K.; Tatsuta, K. Chem. Rev. 1993, 93, 1503. 